DOI: $10.17516 / 1997-1370-0781$

УДК 519.876.5; 004.942

\title{
Input-Output Table Regionalization and Multiregional Input-Output Model Development Algorithm
}

\author{
Yurii S. Ershov*a, Naimdzhon M. Ibragimova, b \\ and Aleksandr I. Dushenin ${ }^{b}$ \\ ${ }^{a}$ Institute of Economics and Industrial Engineering of the $S B R A S$ \\ Novosibirsk, Russian Federation \\ ${ }^{b}$ Novosibirsk National Research State University \\ Novosibirsk, Russian Federation
}

Received 11.10.2020, received in revised form 02.06.2021, accepted 02.07.2021

\begin{abstract}
The main problems of constructing multiregional input-output (IO) models used for the development of spatial and sectoral long-term national economy forecasts are caused by the absence of proper statistics. Therefore, it is necessary to make up the input-output tables (IOTs) based on a limited set of direct and indirect indicators that measure spatial patterns of production, consumption, capital formation, etc., sufficiently accurate for filling up multiregional IO models. The paper discusses Russian IOT spatial mapping problems and proposes an approach to partial automation of the procedures necessary for regional IOT construction (by federal districts). The regionalization was carried out using a static IO model with the bounding sum control. As a result, a set of consistent regional tables for 2015 was developed, with the eight IOT sum equalling Russia's IOT. Based on the estimated regional IOTs, a static multiregional input-output model (OMIOM) across federal districts for 2015 was made up. The model allows us to proceed to the follow-up phase, i. e., developing a semi-dynamic model for long-term national economic projection computations.
\end{abstract}

Keywords: multiregional input-output models, federal districts, types of economic activities, input-output table, supply and use tables.

The article was prepared in accordance with the Research Plan of the IEIE SB RAS, Project 5.6.6.4. (0260-2021-0007). «Tools, technologies and results of analysis, modelling and forecasting of the spatial development of the socioeconomic system of Russia and its specific territories».

Research area: economics.

\footnotetext{
(C) Siberian Federal University. All rights reserved

* Corresponding author E-mail address: eryus@mail.ru, naimdjon.ibragimov@nsu.ru, a.dushenin@g.nsu.ru ORCID: 0000-0003-3526-3727 (Ershov); 0000-0001-8540-5039 (Ibragimov)
} 
Citation: Ershov, Yu.S., Ibragimov, N.M., Dushenin, A.I. (2021). Input-output table regionalization and multiregional input-output model development algorithm. J. Sib. Fed. Univ. Humanit. Soc. Sci., 14(7), 1018-1027. DOI: 10.17516/1997-1370-0781.

\title{
Алгоритм регионализации таблицы «затраты-выпуск» и построения межрегиональной межотраслевой модели
}

\author{
Ю.С. Ершова ${ }^{a}$ Н.М. Ибрагимов ${ }^{\mathrm{a}, 6}$, А.И. Душенин ${ }^{6}$ \\ ${ }^{a}$ Институт экономики и организачии \\ промышиленного производства СО РАН \\ Российская Федерация, Новосибирск \\ ${ }^{6}$ Новосибирский начиональный исследовательский \\ государственный университет \\ Российская Федерачия, Новосибирск
}

\begin{abstract}
Аннотация. Главные проблемы построения межрегиональных межотраслевых моделей, используемых для разработки пространственного и отраслевого разрезов долгосрочных народнохозяйственных прогнозов, обусловлены отсутствием в полном объеме прямых статистических данных, т. е. региональных таблиц распределения товаров и услуг. Расчет этих таблиц приходится осуществлять исходя из ограниченного набора прямых и косвенных показателей, которые позволяют определить пространственные структуры производства, потребления, накопления основного капитала и т. п. с точностью, достаточной для дальнейшего их использования в информационном наполнении межрегиональных межотраслевых моделей. В статье рассматриваются проблемы пространственной разверстки общероссийской таблицы «затраты-выпуск» и предлагается авторский подход к частичной автоматизации процедур, необходимых для построения совокупности региональных таблиц (по федеральным округам). Регионализация производилась с помощью статической межотраслевой модели с контролем окаймляющих итогов. В результате был получен набор непротиворечивых региональных таблиц по состоянию на 2015 г. - сумма восьми таблиц «затраты-выпуск» точно совпадает с общероссийской таблицей. На базе таких оценочных региональных таблиц была построена статическая межотраслевая межрегиональная модель в разрезе федеральных округов РФ за 2015 г., необходимая для выполнения последующего этапа работ - разработки полудинамической модели, используемой для расчета вариантов долгосрочных народнохозяйственных прогнозов.
\end{abstract}

Ключевые слова: межрегиональные межотраслевые модели, федеральные округа, виды экономической деятельности, таблица «затраты - выпуск», таблицы ресурсов и использования.

Статья подготовлена по плану НИР ИЭОПП СО РАН, проект 5.6.6.4 (0260-2021-0007) «Инструменты, технологии и результаты анализа, моделирования и прогнозирования пространственного развития социально-экономической системы России и её отдельных территорий», № 121040100262-7.

Научная специальность: 08.00.00 - экономические науки. 


\section{Introduction}

The diversity of economic and social conditions, the enormous regional differentiation by the level of socioeconomic development, and the importance of a background for the efficient common economic space require accounting for industry-specific and spatial aspects in forecasting and socioeconomic analysis. In its turn, that presumes the use of adequate analytical and prognostic tools. Such studies examine the established trends and their causes and identify the objective, long-term, accidental, short-term factors among them. This is the primary research domain of the Institute of Economics and Industrial Engineering (IEIE) SB RAS, preceding further regional economic forecasting studies (Ershov, 2020; Kuleshov et al., 2013; Ershov, 2016; Ershov, 2015). Many authors representing other research centres also pay much attention to the spatial aspects of Russia's economic development (Ershov, 2020; Mikheeva, 2017). The crucial factor shaping the fundamental economic development trends in different regions is their specialization. Therefore, in-depth analysis is impossible without considering the sectoral structure and the specifics of interregional relations (Mikheeva, 2006). Multiple authors agree on the decisive role of the national factors (Mikheeva, 2018) in the regional economic development, and, at the same time, on the significant impact made by certain regional factors that differentiate the economic growth rates, especially in the crisis periods, to a considerable extent (Ershov, 2012; Granberg et al., 2011).

Apart from the traditional long-term forecasting of the Russian economy in the sectoral and spatial aspects, the Institute of Economics and Industrial Engineering pursues a rather unique line of research regarding the specifics of interregional interactions that cannot be defined without adequate economic-andmathematical tools: coalition analysis, enabling to assess the level of complementarity and interdependence between regional economies, and studies aimed at searching the state of equilibrium and the essence of multiregional systems [Suslov et al., 2019; Vasil'ev, Suslov, 2011; Vasil'ev, Suslov, 2010).
Economic forecasting is not the only domain in which the input-output models of national and multiregional statements can be used. They form the basis for studying such aspects, as, for instance, prediction and analysis of gas emissions (Li, Li, 2020; Wang et al., 2020; Xin et al., 2020) and related energy interlinkages across regions (He et al., 2019; Liu et al., 2021) or investment efficiency assessment (Mikheeva et al., 2011).

Obviously, the quality of the results obtained using multi-regional input-output models (MIOMs) depends directly on the validity of their content. At present, the model-software complex of the Institute comprises several interrelated models. A static multi-regional input-output model is essential as an optimization model (OMIOM). Moreover, it serves as a foundation for all other structures.

The primary purpose of the modelsoftware complex (MSC) is to coordinate the macroeconomic, sectoral and regional long-term forecasts regularly, experimentally estimate the predicted scenarios for the development of the Russian national economy, and assess the role of territorial and foreigneconomic factors in shaping the spatial structure of the economy (Granberg et al., 2007).

A previously developed MSC was used as a blueprint for this work. Along with a point IOM, it comprises two spatial IOMs covering 40 types of economic activities ${ }^{1}$ (further on referred to as sectors); i. e., a static (2013) multiregional model across 8 federal districts for the base year 2013, and a semi-dynamic multiregional model covering the period up until 2030. The models were filled with information manually.

After Rosstat published the IOTs for 2015 and the Ministry of Economic Development presented the macro-indicators of national economic development until 2036, accelerating the procedures for filling up the informational content of the models became an urgent task.

The paper outlines the main results of building a 2015 static MIOM for the Russian Federation and entering current information into the models. Besides being valuable on

\footnotetext{
According to OKVED1.1 (Russian National Classifier of Types of Economic Activity).
} 
their own, these results also constitute a necessary step for the scheduled work on estimating sectoral and spatial scenarios for long-term national economic forecasts.

\section{Filling up a static multiregional \\ input-output model (base year problem)}

Since the official statistical data in Russia lack a regional IOT system, the regionalization of such tables broken by federal districts is a priority in the OMIOM building. Here, the base tables were regionalized based on the national tables of resources and the use of goods and services in 2015, compiled by Rosstat (Federal'naia sluzhba gosudarstvennoi...).

The regional IOT accessibility issue is not unique for the Russian statistics. In Brazil and China, for instance, regional reporting tables are compiled regularly, while in many countries, including Russia, they do not exist (Kuleshov et al., 2013; Suslov et al., 2017). For this reason, there is a need for multiple assessment methods that do not require enterprise surveys. The most popular methodology is based on location quotients. In line with this algorithm, relative-share ratios in the regional and national economy sectoral structure are calculated. If the figure is less than 1 , it allows applying the national direct input coefficient to the relevant cell of a regional table. On the other hand, if the allocation quotient exceeds 1 , the national coefficient is increased proportionately to be used in a regional table (Kuleshov et al., 2013). A. Saiapova suggested her own regional table building method for Bashkortostan (Saiapova, Sutiagin, 2001). N. Mikheeva describes an IOT assessment methodology and results for the Russian Far East (Mikheeva, 2005).

For the estimation of regional IOTs for 2015, the IEIE SB RAS methodological approaches were used (Ershov, 2011).

The calculation of the regional IOT indicators begins with a sectoral classifier selection. In this study, the indicators were calculated across 46 sectors of regional economies.

The classifier was selected because OKVED1.1 (the basis for the Russian table of resources and use of goods and services of 2015) aggregates some types of activity (sec- tors of the economy) that differ in the structure of production costs and production geography. Therefore, our classifier separates such activities (sectors) as «production of coke and petroleum products» and «ore mining». Ferrous and non-ferrous metallurgies are separate for the same reason. Such aggregates were decomposed pro rata the value of the dispatched products.

The following critical stage of the study was to calculate regional output indicators currently published by Rosstat only as a common value for Russia.

There can be no unified method for the spatial allocation of output indicators; the differences between the approaches are caused by the difference in the content of the data provided by statistical sources. The main principles for calculating regional output indicators are as follows:

1. Distribution proportionately to the amounts of the value-added (VA). This method is appropriate for education, healthcare, public administration, and other services that cannot have significant cross-regional differences in terms of the value-added to the output ratio, as well as in the structure of intermediate consumption. Additional information, such as spatial employment structure (Elektronnye tablitsy statistiki $R F$...), spatial tax revenue structure (without VA tax and excise duties) (FNS [Federal Tax Service]...) (the latter is very close to the spatial VA structure) is important for public administration, where a part of the VA is not broken down by regions.

2. The estimates are based on indirect data without reference to any published regional VA data. This approach is employed for the financial activity where only $10-15 \%$ of the total Russian VA is broken down by regions; the regional figures are calculated based on employment and tax statistics.

3. Breaking down pro rata to incomplete regional output data. This principle is used for agriculture: although all publications on agricultural production are claimed to cover «all categories of enterprises», the sum of regional outputs does not equal the total national output presented in the national accounts (Regiony Rossii. Sotsial'no-ekonomicheskie...). 
4. Breaking down pro rata physical production indicators. This approach applies to mono-sectors, and it turns out that the actual breaking down by regions is based on the average prices in Russia; however, it only improves the consumer qualities of the mathematical apparatus, although the obtained input values may deviate from the official figures due to use of region-differentiated prices in the calculations. Furthermore, breaking down pro rata physical production (extraction) can also result in deviation from the official input data («quantity of dispatched goods...») because the latter account for commercial products only. Consequently, the data in value terms may lack, for instance, information about coke production in a particular region if fully intended for in-plant turnover.

The principle of breaking down pro rata physical indicators is used for fishery and fish farming, coal, oil, gas, ferrous metal ore, coke, petrochemical production, electric and heating power generation (Regiony Rossii. Sotsial'noekonomicheskie...; Elektronnye tablitsy statistiki RF...).

5. Breaking down pro rata «quantity of dispatched products...» (Federal'naia sluzhba gosudarstvennoi statistiki...) means direct multiplication of the total outputs by the regional shares of dispatched products, if nearly all products are produced by organizations (legal entities). It is established by comparing the total employment in a particular sector and the average annual number of the persons employed by organizations. If the difference between the total employment and the average annual headcount of organizations is significant, and if the cross-regional difference in the ratio is high, the difference between the total output and the sum of outputs over organizations is defined at the national level. Assuming that the workforce productivity between the organization employees and others is the same, regional indicators on the dispatched products are counted up.

Besides manufacturing sectors, this method is also applied to construction. Indices on construction volumes, published by regions, relate to contractors only. Overall, it covers only around $60 \%$ of the Russian construction sector output. Moreover, the proportional increase of regional indicators may distort the actual spatial structures due to considerable crossregional differences in employment ratio in construction entities to the overall employment in the construction sector.

A similar approach is also used for the spatial output allocation in "Operations with real estate, ... «

6. For land transportation, pipeline, and communication sectors, the national output is broken down proportionately to the detailed data from the «П1» corporate output statistical form. For this method, major errors are unlikely since the share of individual entrepreneurs and households in such sectors is insignificant.

Another essential stage in building up regional IOTs is estimating regional consumptions and the final household consumption structure.

There are various approaches to be used for the spatial breakdown of this indicator:

1. Breaking down pro rata regional outputs. This principle underlies consumption estimates for healthcare, education and similar services since nearly $98 \%$ of products in such sectors fall on final consumption, and the expenditures for intermediate consumption in other sectors are small.

2. Breaking down pro rata incomplete data about regional consumption. Such data are published on electric power consumption (in physical terms) as well as consumption of postal and telecommunications services (in purchase prices) or tour services.

3 . Breaking down pro rata personal income data. It applies, first of all, to the sectors where outputs depend heavily on the purchasing power of the population (agriculture, food and light industries, trade and transportation service and so on) (Regiony Rossii. Sotsial'noekonomicheskie pokazateli...).

4. Estimates based on indirect data. The approach is used for financial operations: regional indicators are calculated based on distribution indicators on credit institutions and their branches in federal districts provided by fiscal control bodies (Regiony Rossii. Sotsial'noekonomicheskie pokazateli...).

5. Estimates based on the national table of resources and use of goods or services (Fed- 
eral'naia sluzhba gosudarstvennoi statisti$k i . .$.$) . For instance, if household consumption$ of some mining sectors is missing, the regional consumption is assumed as zero.

Final consumption expenditures of government agencies include expenses for collective services (more $95 \%$ of which is the consumption by the government agency and the maintenance of the national defence) and individual services (where around $90 \%$ fall on education, healthcare and others, namely physical training, social security, art and culture). In such sectors, expenditures for intermediate consumption in other sectors are small, accounting for approximately $3-4 \%$ of the output; therefore, it would be reasonable to assume that the proportions will be the same in each region (Granberg et al., 2007). Thus, the final consumption expenditures of government agencies in such intangible service sectors in each region can be determined pro rata regional outputs. Regional expenditures in other sectors are determined following the spatial structure of the final household consumption.

Fixed capital investment data in the IOTs are broken down by three sectors: machine engineering, construction, real estate operations, lease and services $(\mathrm{R} \& \mathrm{D}$ and related drilling). The available statistics (Elektronnye tablitsy statistiki $R F$...) allows us to break down the aggregated fixed capital by the above three positions; the data are incomplete but close to the cumulative investments; the total can be reached through pro rata increase of all the three elements.

We applied the following approach to estimate the export/import spatial structure:

1. For tangible sectors, direct customs statistics from federal districts were used (Tamozhennoe upravlenie...).

2. For intangible services, export was estimated pro rata the data on regional outputs, and import was evaluated pro rata the data on regional final household consumption.

In the initial breaking down of regional intermediate consumption by sectors for all regions, nationwide technical coefficients (intermediate consumption per unit) were used, based on the national goods and service con- sumption table for 2015 (Federal'naia sluzhba gosudarstvennoi statistiki...).

As a result of the above-described procedures, estimated approximated regional IOTs are generated. Naturally, such initial estimates may be misaligned with regard to particular sectors. Eliminating such disbalance is the next step. For some sectors, disbalance will be insignificant due to the selected method and require simple formal balancing techniques. In case of a considerable disbalance, non-formalized expert assessments are necessary.

\section{Balancing regional input-output tables}

If $e_{i}^{r}$ is the disbalance in the output of goods (services) in sector $i$ in a region $r$, then

$$
\begin{aligned}
& e_{i}^{r}=x_{i}^{r}-\sum_{j=1}^{n} \boldsymbol{a}_{\boldsymbol{i}}^{r} x_{j}^{r}-\boldsymbol{\alpha}_{i}^{r} z^{r}-\sum_{s \neq r} x_{i}^{r s}+ \\
& +\sum_{s \neq r} x_{i}^{s r}-\boldsymbol{v}_{\boldsymbol{i}}^{\boldsymbol{r} \boldsymbol{k}}+\boldsymbol{v}_{\boldsymbol{i}}^{\boldsymbol{k r}}-\boldsymbol{q}_{\boldsymbol{i} i}^{r} ;
\end{aligned}
$$

Notation:

$x_{i}^{r}-$ output of products (services) in sector $i$ in region $r$

$z^{r}$ - final consumption in region $r$;

$x_{i}^{r}-$ deliveries of sector $i$ products from region $r$ to regions;

$x_{i}^{S}-$ deliveries of sector $i$ products from region $s$ to region $r$;

$\boldsymbol{v}_{\boldsymbol{i}}^{\boldsymbol{r}}$ - export of product $i$ goods (services) from region $r$

$\boldsymbol{v}_{\boldsymbol{i}}^{\boldsymbol{k}}$ - import of product $i$ goods (services) from region $r$.

$\boldsymbol{a}_{\boldsymbol{i} \boldsymbol{j}}^{\boldsymbol{r}}$ - inputs from sector $i$, needed per unit of output of sector $\mathrm{j}$ in region $r$;

$\boldsymbol{\alpha}_{\boldsymbol{i}}^{r}$ - share of product $i$ in the total final consumption in the region $r\left(\sum_{i=1} \alpha_{i}^{r}=1 \alpha_{i}^{r}=1\right)$;

$\boldsymbol{q}_{p i}^{r}$ - volume of the final product in the part of product $i$ of region $r$, not included in the maximized part of final consumption (mostly, gross accumulation of fixed capital).

Depending on a sector, different formal methods of eliminating disbalance may apply:

1. If products are transportable (sectors 1-29), disbalance is adjusted by varying inflow/ outflow values (see more detailed description below): 


$$
e_{i}^{r}=\sum_{s \neq r} x_{i}^{r s}-\sum_{s \neq r} x_{i}^{s r}
$$

2. If the intermediate product consumption depends on the natural conditions in a region (sectors $30,31,32$ ) or trade mark-ups (35), inputs per unit are adjusted:

$$
\begin{gathered}
a_{i j}^{r(\text { new })}=\gamma_{i}^{r} a_{i j}^{r(\text { old })}, \text { where } \\
\gamma_{i}^{r}=\frac{\sum_{j=1}^{n} a_{i j}^{r(\text { old })} x_{j}^{r}+e_{i}^{r}}{e_{i}^{r}}
\end{gathered}
$$

3. For non-transportable products (sectors $33,34,36,40-47)$, the final consumption values are adjusted:

$$
y_{i}^{r(\text { new })}=g_{i}^{r} y_{i}^{r(\text { old })} \text {, где } g_{i}^{r}=\frac{y_{i}^{r(\text { old })}+e_{i}^{r}}{e_{i}^{r}}
$$

4. Disbalance in the transport sector (37-39) is eliminated by breaking down the intermediate transport consumption into three parts: the costs for intraregional, cross-regional and external transportation:

$$
\begin{aligned}
& x_{\tau j}^{r}=\boldsymbol{a}_{\tau j}^{r r} x_{j}^{r}+\sum_{s \neq r} c_{r \tau j}^{r s} x_{j}^{r s}+\sum_{s \neq r} c_{r \tau j}^{s r} x_{j}^{s r}+ \\
& +\boldsymbol{d}_{\boldsymbol{\tau} j}^{r k} v_{j}^{r k}+\boldsymbol{d}_{\boldsymbol{\tau} j}^{k r} v_{j}^{k r} ; \boldsymbol{\tau} \in \mathrm{T}
\end{aligned}
$$

\section{Notation:} gion $r$

$x_{\tau j}^{r}-$ volume of transport services in re-

$\boldsymbol{a}_{\tau j}^{r \boldsymbol{r}}$ - transport inputs of region $r$ for intraregional shipment of a unit of products $j$ in region $r$;

$c_{r \tau j}^{r s}$ - transport inputs of region $r$ for outflow of a unit of products $j$ from region $r$ to region $s$;

$c_{\boldsymbol{r} \tau \boldsymbol{j}}^{\boldsymbol{s r}}$ - transport inputs of region $r$ for inflow of unit of products $j$ from region $s$ to region $r$;

$\boldsymbol{d}_{\boldsymbol{\tau} j}^{r \boldsymbol{k}}-$ transport inputs of region $r$ for export of unit of products $j$;

$\boldsymbol{d}_{\boldsymbol{\tau} j}^{\boldsymbol{k} \boldsymbol{r}}$ - transport inputs of region $r$ for import of unit of products $j$;

Why can adjusting disbalance in the transport sector through changing input coefficients be problematic? The thing is that the direct input coefficients account for only intra-regional transportation, so their adjust- ment can be impossible. For instance, the Central Federal District (CFD) has pipelines for transporting oil and gas. The output of such products in CFD equals 0 (i. e. $a_{t j}^{r r}=0$ ). Therefore, adjusting the input ratio will not generate any meaningful results. Furthermore, the overall standard form of a regional IOT would differ from the national table. The standard IOT form for the regions of Russia is presented in Fig. 1.

Regional tables have four quadrants. The intermediate consumption quadrant shows the product inputs for sectoral outputs, including intra-regional transportation (row $X_{\tau}^{r r}$ ). The final consumption quadrant in a regional IOT is the same as in the national table, except inflow - outflow variables (columns $X^{r s}, X^{s r}$ ). The structure of the value-added quadrant is similar to the third quadrant in the national IOT. The «foreign transportations» rows comprise inflow, outflow transportation, export and import of the products of relevant sectors (rows $\left.X_{\tau}^{r s}, X_{\tau}^{s r}, V_{\tau}^{r k}, V_{\tau}^{r k}\right)$. The sum of sectoral outputs in the table should be equal to the sum of product outputs with the total value of foreign transportations.

Transportation rows in the regional IOTs should satisfy the equation:

$$
\begin{aligned}
& x_{\tau j}^{R F}=\sum_{r=1}^{R} x_{\tau j}^{r r}+\sum_{r=1}^{R} \sum_{s \neq r} x_{\tau j}^{r s}+\sum_{r=1}^{R} \sum_{s \neq r} x_{\tau j}^{s r}+ \\
& +\sum_{r=1}^{R} v_{\tau j}^{r k}+\sum_{r=1}^{R} v_{\tau j}^{k r} ; \boldsymbol{\tau} \in \mathrm{T} ; j=\overline{1, n}
\end{aligned}
$$

The biggest challenge is estimating interregional flows and transport coefficients. The interregional flows of goods were estimated with the following assumptions:

1. Network principle of transport flow presentation. The estimated interregional flows are presented based on the network principle: i. e., interregional relations is a system limited to relations between neighbouring regions; hence, some flows from one region to another are fully or partially in transit.

2. Absence of counter-flows. The estimated values of interregional flows of goods are accurate to the net balance; for some goods, counter-deliveries are absent or negligible. 


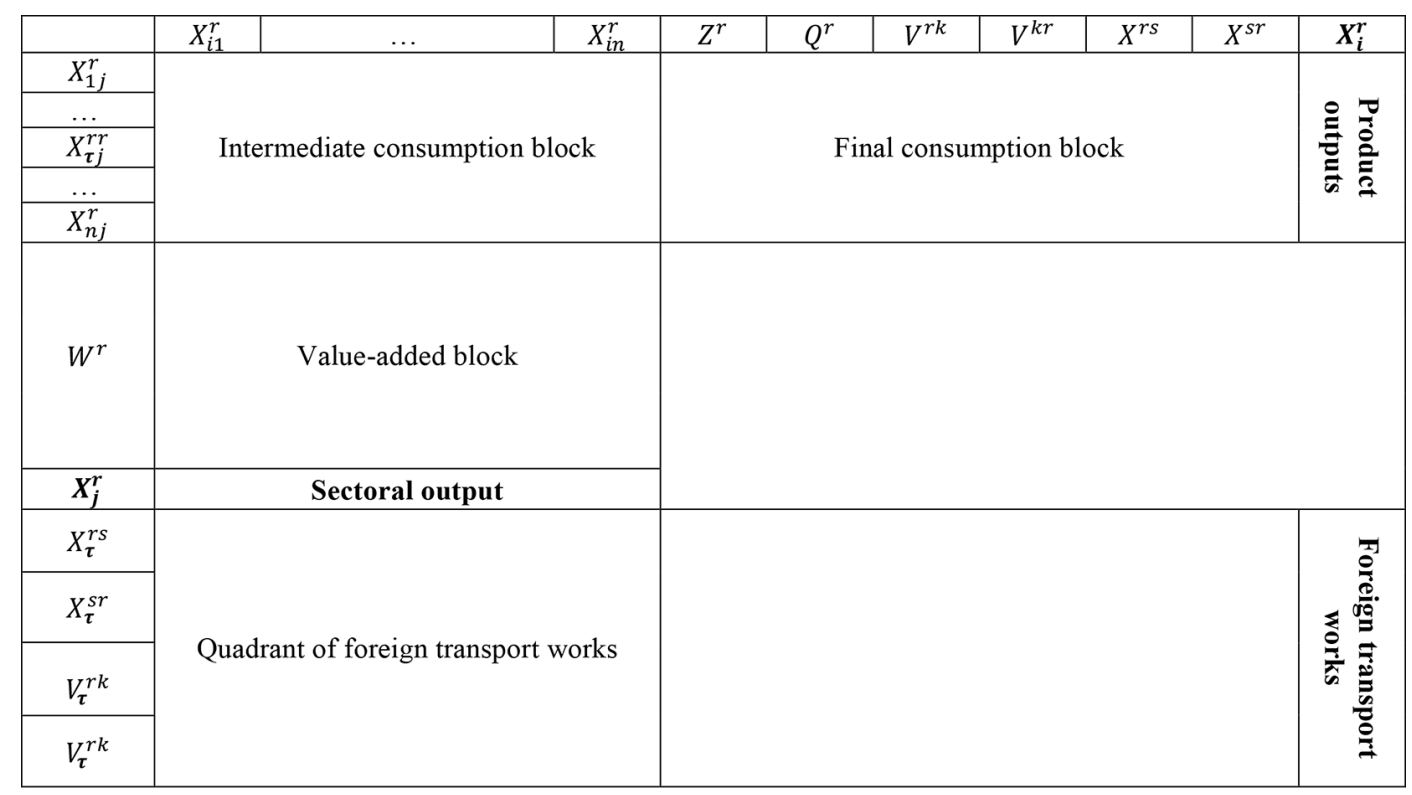

Fig. 1. The standard form of an IOT for the regions of the Russian Federation

3. Trading by «conventional centres». Formal breakdown of transportation inputs for interregional deliveries relies upon the «from a conventional production centre of a producing region to a conventional consumption centre of a consuming region» principle. It allows equating outflow transport coefficients in a region to export coefficients (inflow coefficients to import coefficients accordingly). Different sectors may have different conditional centres.

4. Inflow inputs exceed outflow inputs. The inflow coefficients are assumed to exceed the outflow coefficients on product transportation. Besides the distance covered by the inbound and outbound transport (from the regional boundaries to the centre and vice versa), the inbound products are also delivered to all points within a region.

The interregional trade flows were estimated by a qualitative rationale since statistical information about the vectors and scope of goods flows can hardly be found. For instance, the whole inbound / outbound traffic for FEFD to other regions was assumed as going through the Siberian Federal District; for NCFD - only through SFD; all deliveries from SFD westbound - only through UFD. In the case of mul- tivariance, the knowledge about domestic economic activity applied.

Final balancing. By implementing this algorithm, some discrepancies between the regional indicators and the corresponding nationwide values could be revealed. However, the regional totals (totals refer to rows and columns) equal to the national totals. The bias was corrected with the multi-stage biproportional correction (RAS type) of regional tables. The result of the work was a system of 8 regional input-output tables, with the indicators' values coinciding with the national ones.

\section{Conclusion}

The algorithm for building up a system of regional IOTs outlined in the paper cannot remain unchanged for a long period. It is necessary to adjust the parameters used for automated estimates of the tables from time to time and all the numerical coefficients. Moreover, it affects most of all the transport blocks of the model, where significant changes of particular coefficients may occur due to, for example, commissioning new pipelines or modifications in the import-export geography. Developing regional IOTs remains quite labour-intensive 
work that relies upon many information sources. Algorithms, however, dramatically reduce the time of building up initial approximation-balanced system of IOTs, in their totality reaching the cumulative production and consumption indicators, the volumes of intersectoral flows of goods and services, presented in the consolidated national table.

\section{References}

Aganbegyan, A.G., Mikheeva, N.N., Fetisov, G.G. (2013). Modernization of the real sector of the economy: Spatial aspects. In Regional research of Russia, 3(4), 309-323.

Elektronnye tablitsy statistiki RF [Spreadsheets of RF statistics]. In Proizvodstvo promyshlennoy produktsii v natural'nom vyrazhenii po polnomu krugu proizvoditeley [Production of industrial products in physical terms by the full range of manufactures]. Available at: http://sophist.hse.ru/rosstat.shtml (accessed 13 March 2020).

Elektronnye tablitsy statistiki RF [Spreadsheets of RF statistics]. In Elektrobalans i moshchnost' elektrostantsii [Electrical balance and capacity of power plants]. Available at: http://sophist.hse.ru/rosstat.sht$\mathrm{ml}$ (accessed 13 March 2020).

Elektronnye tablitsy statistiki RF [Spreadsheets of RF statistics]. In Investitsii v ekonomiku RF [Investment in the Russian economy]. Available at: http://sophist.hse.ru/rosstat.shtml (accessed 13 March 2020).

Elektronnye tablitsy statistiki RF [Spreadsheets of RF statistics]. In Svedeniia o srednespisochnoy chislennosti $i$ nachislennoy zarabotnoy plate rabotnikov organizatsiy $R F$ po vidam ekonomicheskoy deiatel'nosti po federal'nym okrugam i sub'ektam RF [Information on the average headcount and accrued salaries of employees of organizations of the Russian Federation by type of economic activity in federal districts and subjects of the Russian Federation]. Available at: http://sophist.hse.ru/rosstat.shtml (accessed 13 March 2020).

Ershov, Iu.S. (2020). Multiregional differentiation and donating and recipient regions: Diversity of assessments and conclusions. In Regional Research of Russia, 10(1), 20-28. DOI: 10.1134/S2079970520010037.

Ershov, Iu.S. (2012). Spatial aspect of the Russian economy and prospects of its development: before and after the crisis. In Regional research of Russia, 2(1), 1-11.

Ershov, Iu.S. (2011). Regionalizatsiia narodnokhoziaistvennykh tablits «zatraty-vypusk» [Regionalization of national economic input-output tables]. In ECO [ECO], 6, 119-138.

Ershov, Iu.S. (2016). Features of regional economic development in Russia in 1999-2013. In Regional research of Russia, 6(4), 281-291. DOI: 10.1134/S2079970516040079.

Ershov, Iu. S (2015). The Siberian Federal District in the modern Russian economy. In Regional Research of Russia, 5(1), 58-67.

Federal'naia sluzhba gosudarstvennoi statistiki [Federal State Statistics Service]. In Ofitsial'naia statistika. Natsional'nye scheta [Official statistics. National accounts]. Available at: https://www.gks.ru/ storage/mediabank/tri-2015.xlsx (accessed 13 March 2020).

FNS [Federal Tax Service]. In Otchet po forme 1-NOM po sostoianiiu na 01.01.2016 [1-NOM report as of 01.01.2016]. Available at: https://www.nalog.ru/html/sites/www.new.nalog.ru/docs/otchet/1nom010116reg.xlsx (accessed 13 March 2020).

Granberg, A.G., Mikheeva, N.N., Ershov, Iu.S., Kuleshov, V.V., Seliverstov, V.E., Suslov, V.I., Suspitsyn, S.A., Minakir, P.A. (2011). The impact of the global crisis on the strategy of spatial socioeconomic development of the Russian Federation. In Regional research of Russia, 1(1), 2-14.

Granberg, A.G., Suslov, V.I., Ershov, Iu.S., Ibragimov, N.M., Mel'nikova, L.V. (2007). Strategii territorial'nogo i regional'nogo razvitiia ekonomiki Rossii [Strategies for the territorial and regional development of the Russian economy]. In Problemy i perspektivy tekhnologicheskogo obnovleniia rossiyskoi ekonomiki [Problems and prospects of technological renewal of the Russian economy], 463-484.

Gulakova, O.I., Ershov, Iu.S., Ibragimov, N.M., Novikova, T.S. (2018). Evaluation of the public efficiency of an infrastructure project: a case study of the Eastern Siberia - Pacific Ocean-2 Oil Pipeline. In Regional Research of Russia, 8(2), 193-203. DOI: 10.1134/S2079970518020053. 
He, P., Ng, Ts. Sh., Su, B. (2019). Energy-economic resilience with multi-region input-output linear programming models. In Energy Economics, Elsevier, 84, 104569.

Heijman, W. and Schipper, R.A. (2010). Space and Economics: An Introduction to Regional Economics. Wageningen, Wageningen Academic Publishers, $266 \mathrm{p}$.

Kuleshov, V.V., Seliverstov, V.E., Suslov, V.I., Suspitsyn, S.A. (2013). Siberian School of Regional Studies in the RAS Presidium Program «Fundamental Problems of the Spatial Development of the Russian Federation: Interdisciplinary Synthesis. In Regional research of Russia, 3(2), 113-122.

Li, X., Li, Y.P. (2020). A multi-scenario ensemble simulation and environmental input-output model for identifying optimal pollutant- and CO2-emission mitigation scheme of Guangdong province. In Journal of Cleaner Production, Elsevier, 262, 121413. DOI: 10.1016/j.jclepro.2020.121413.

Liu, Z., Huang, Q., He, Ch., Wang, Ch., Wang, Y., Li, K. (2021). Water-energy nexus within urban agglomeration: An assessment framework combining the multiregional input-output model, virtual water, and embodied energy. In Resources, Conservation \& Recycling, Elsevier, 164, 105113.

Mikheeva, N.N. (2017). Diversification of regional economic structure as a growth strategy: Pros and cons. In Regional research of Russia, 7(4), 303-310. DOI: 10.1134/S2079970517040062.

Mikheeva, N.N. (2018). Factors of growth in Russian regions: Adapting to new realities. In Regional research of Russia, 8(4), 332-341. DOI: 10.1134/S207997051804007X.

Mikheeva, N.N. (2006). The Russian economy resource sector: Its scale and interindustry interactions. In Studies on Russian economic development, 17(2), 136-148.

Mikheeva, N.N., Novikova, T.S., Suslov, V.I. (2011). Evaluation of investment projects based on a complex of interindustry and multiregional models. In Studies of Russian economic development, 22(4), 401-409.

Mikheeva, N.N. (2005). Statisticheskaia otsenka tablits «zatraty-vypusk» dlia rossiyskogo Dal'nego Vostoka [Statistical evaluation of input-output tables for the Russian Far East]. In Prostranstvennaia ekonomika [Spatial Economics], 2, 61-79.

Okamoto, N. and Ihara, T. (2003). Spatial Structure and Regional Development in China: Multiregional Input-Output Approach. IDE Development Perspective, 5, 208 p.

Regiony Rossii. Sotsial'no-ekonomicheskie pokazateli [Regions of Russia. Socioeconomic indicators]. Available at: https://rosstat.gov.ru/bgd/regl/B16_14p/Main.htm (accessed 13 March 2020).

Saiapova, A.R., Sutiagin, V.S. (2001). Opyt postroeniia i analiza mezhotraslevogo balansa regiona v kontseptsii SNS [Experience in constructing and analyzing the input-output balance of the region in the concept of SNA]. In Problemy prognozirovaniia [Forecasting problems], 2, 85-96.

Tamozhennoe upravlenie [Customs Directorate]. In Vneshniaia torgovlia TSFO [Foreign trade of the Central Federal District]. Available at: https://ctu.customs.gov.ru/folder/273798 (accessed 13 March 2020).

Suslov, V.I., Baranov, A.O., Lavrovsky, B.A. (2017). Macroeconomic model of the scientifictechnological progress. $10^{\text {th }}$ International Conference «Management of Large-Scale System Development». Moscow. DOI: 10.1109/MLSD.2017.8109692

Suslov, V.I., Domozhirov, D.A., Ibragimov, N.M. (2019). Balance, state and coalition stability of multiregional economic systems: Impact of openness. $12^{\text {th }}$ International Conference «Management of LargeScale System Development». Moscow. DOI: 10.1109/MLSD.2019.8911081

Vasil'ev, V.A., Suslov, V.I. (2011). Edgeworth Balance in a Model of Multiregional Economic Relations. In Journal of Applied and Industrial Mathematics, 5(1), 130-143.

Vasil'ev, V.A., Suslov, V.I. (2010). On the Unblockable States of Multiregional Economic Systems. In Journal of Applied and Industrial Mathematics, 4(4), 578-587.

Wang, X., Klemes, J.J., Wang, Y., Dong, X., Wei, H., Xu, Z., Varbanov, P.S. (2020). Water-EnergyCarbon Emissions nexus analysis of China: An environmental input-output model-based approach. In $A p$ plied Energy, Elsevier, 261 (C), 114431.

Xin, Ch., Zhu, Y., Shen, J. (2020). Input-output dynamic model for optimal environmental pollution control. In Applied Mathematical Modelling, Elsevier. 83, 301-321. 